\title{
Leukemia Stem Cells in Blood Cells; Focused on Acute Myeloid Leukemia
}

\author{
Ji Yoon Lee ${ }^{\dagger}$ \\ Department of Biomedical Laboratory Science, College of Health Sciences, \\ Sangji University, Wonju 26339, Korea
}

\begin{abstract}
It is known that acute myeloid leukemia (AML) is a heterogeneous blood cancer, which is enormously propagated by self-renewing leukemia stem cells (LSCs). The persistence of LSCs after chemotherapy can contribute to minimal residual disease and relapse by LSCs can be evoked promptly. Elucidating special molecules and cellular activity of LSCs is an extremely important to eliminate AML. Despite an increasing understanding of the origin of LSCs by incessant study, AML still remains a notorious disease with high mortality. An exact identification of the LSCs that sustain the proliferation of neoplastic clone is a fundamental issue in AML treatment. CD34+CD38- conventional phenotype is overall regarded as LSCs, but it has a limitation that is still hard to demarcate exactly due to similarity with normal hematopoietic stem cells (HSCs). Not all primary blasts and progenitors have equal function, thus a bona fide marker for identifying LSCs from HSCs is needed in hematologic malignancy, especially in AML. These findings have direct important implications in both in mechanistic study of LSCs as well as in the strategies of more effective therapies. In this review, I briefly summarized current advances in LSCs biology, focusing on membrane markers and a functional behavior of LSCs in AML treatment with monoclonal antibodies. Ultimately, it may be helpful in overviewing the status of LSC research, while expecting the clinic benefits of target therapy by specific inhibition.
\end{abstract}

Key Words: Leukemia stem cells, Surface marker, Acute myeloid leukemia

\section{INTRODUCTION}

Acute myeloid leukemia (AML) is heterogeneous blood cancer, which is accumulated by malignant blasts and closely involved in proliferation of leukemia stem cells (LSCs) (Hope et al., 2003, Ferrara et al., 2013). A rare population of stem cells, having self-renewal and differentiation, allows for the maintenance and proliferation of cancer and has been studied in recent years (Hamburger et al., 1977; Jordan et al., 2006). Controversies for existence of cancer stem cells (CSCs) including LSCs have been still ongoing, but evidence has continuously shown for restricted cells with leukemic clonogenic activity by xenograft mouse model in AML (Lapidot et al., 1994). In addition, a role of LSCs with mechanism of marker proteins has been specifically demonstrated (Dieter et al., 2011; Bonnet et al., 1997; Jin et al., 2006; Claudia et al., 2014). Most studies of LSCs showed suppression of their homing and engraftment without leukemic properties, when specific inhibition for LSC marker applied. Because LSCs can drive cancer growth and relapse, the deepening of understanding of leukemogenesis is crucial to treat AML. Since John Dick et al addressed the CD34+CD38- cells as a LSCs by immunophenotype (Lapidot

*Received: February 21, 2017 / Revised: March 23, 2017 / Accepted: April 2, 2017

${ }^{\dagger}$ Corresponding author: Ji Yoon Lee. Department of Biomedical Laboratory Science, College of Health Sciences, Sangji University, Wonju 26339, Korea. Tel: +82-33-738-7684, Fax:+82-33-738-7683, e-mail: leejiyoon@sangji.ac.kr

(C) The Korean Society for Biomedical Laboratory Sciences. All rights reserved.

(c) This is an Open Access article distributed under the terms of the Creative Commons Attribution Non-Commercial License (http://creativecommons.org/licenses/by-nc/3.0/) which permits unrestricted non-commercial use, distribution, and reproduction in any medium, provided the original work is properly cited. 
et al., 1944), CD34+CD38- cells by NOD/LtSz-scid IL$2 \mathrm{R} \gamma^{\text {null }}$ mice (termed NSG) model have been referred to as LSCs (Bonnet et al., 1997; Hope et al., 2004). These immunodeficient mice can allow superior engraftment of human stem cells, unlike in immunocompetent mice. Because hematologic reconstitute does not completely achieve in vitro, repopulating should be confirmed via in vivo system. Thus NOD/LtSz-scid IL-2R $\gamma^{\text {null }}$ mice, which can strongly provide a results for repopulation, has been regarded as available tool to identify LSCs. CD34+CD38- cells by FACS sorting are easily infiltrated into bone marrow (BM) of NOD/LtSz-scid IL-2R $\gamma^{\text {null }}$ mice and generated all lineage hematopoietic cells including T, B and NK cells, indicating CD34+CD38- cells as a representative stem cells. However, fatal drawback of CD34+CD38- population is that it suggested as a representative phenotype in both LSCs and normal hematopoietic stem cells (HSCs) (Ailles et al., 1997; Bhatia et al., 1997). Besides, because AML-LSCs display functional heterogeneity against chemotherapy, not all LSCs could be detected in the only CD34+CD38- population. Some LSCs, CD34+CD38+ cells or other compartments were found to sustain LSCs, when more severe models induced. (Taussig et al., 2008; Taussig et al., 2010). Surface marker is important to confirm the biologic activity with LSC marker from clones of phenotypic cell fractions in LSC study. NOD/LtSz-scid IL-2R $\gamma^{\text {null }}$ mice, which are deleted function of T, B, and NK cells by ablation of IL-2R receptor, are used to address the capacity of LSCs by repopulating of the cancer cells, it allows researcher to further investigate mechanism of development and mutation in leukemogenesis under human like condition (Lapidot et al., 1944; Saito et al., 2010; Ishikawa et al., 2005). Finding out these rare cell populations generating the leukemia in NOD/LtSz-scid IL$2 \mathrm{R} \gamma^{\text {null }}$ mice is the starting point of LSC study. The first experiment for AML-LSC in NOD/LtSz-scid IL-2R $\gamma^{\text {null }}$ mice showed that LSCs are exclusively contained in CD34+ CD38- cells (Ishikawa et al., 2007). Furthermore, both CD34and CD34+CD38+ AML cells failed to stabilize engraftment, in spite of the transplantation with large number of cells, compare to those of CD34+CD38- cells. These data is not consistent with previously mentioned data from Taussig et al., 2010. Although these contradictions containing variation exist, the reason LSCs study should continue is that because it could be provided therapeutic index separating LSCs from HSCs in definitive differences with functional properties. Although it may be difficult to exact identify LSCs due to several conundrums, suppression of LSCs by advanced protein inhibitors such as monoclonal antibody and peptides has also revealed effective treatment in AML. These outstanding discoveries of surface markers in LSCs let us isolate high enriched LSCs, resulting in advanced opportunities to investigate LSCs. Here, I briefly summarized the markers for LSC, which are ongoing studies and are trying in clinic application. Identifying marker protein also raises the possibility of therapeutic benefits through specific inhibition in cancer biology including solid cancer as well as hematologic malignancy.

\section{Typical phenotypes of LSCs in AML I - from the beginning of LSC seeking}

There are several types including M0, M1, M2, M3, M4, M5, M6, M7 subtypes in AML. Among them, M3 is known as acute promyelocytic leukemia (APL) accumulating immature promeyloblasts, but not stem cells. M6 and M7 are categorized form of acute erythroid and megakaryoblastic leukemia. Other groups possess LSC cells except M3, M6 and M7. The CD34+CD38- compartment in particular, was shown to contain both LSCs as well as HSCs. By reported data from Epport K et al (Eppert et al., 2011), frequency of major CD34+CD38- phenotype in AML patients is diversely shown. Besides CD34+CD38- compartment, CD45 ${ }^{\mathrm{dim} / \mathrm{low}}$ is expressed on leukemia blasts as well as LSCs, but not HSCs (Lacombe et al., 1997; Feller et al., 2004). In contrast, CD45 $5^{\text {bright }}$, hematopoietic marker, is expressed in normal hematopoietic stem cells but not LSCs. Thus, CD34+CD38CD45 ${ }^{\mathrm{dim}}$ phenotype can distinctly point out the LSCs. Interestingly, unarguable difference between isolated CD34+ CD38-CD45 ${ }^{\text {dim }}$ cells and CD34+CD38-CD45 $5^{\text {brigh }}$ cells exists, when CFU-colony occurred. Typical CFU-colonies including granulocyte, erythrocyte, macrophage, megakaryocyte (GEMM), granulocyte, macrophage (GM), erythroid (E) were evenly found in HSCs. However, AML-LSCs derived colonies mainly formed GEMM and GM and aberrant morphologies were observed such as very tiny colonies and 

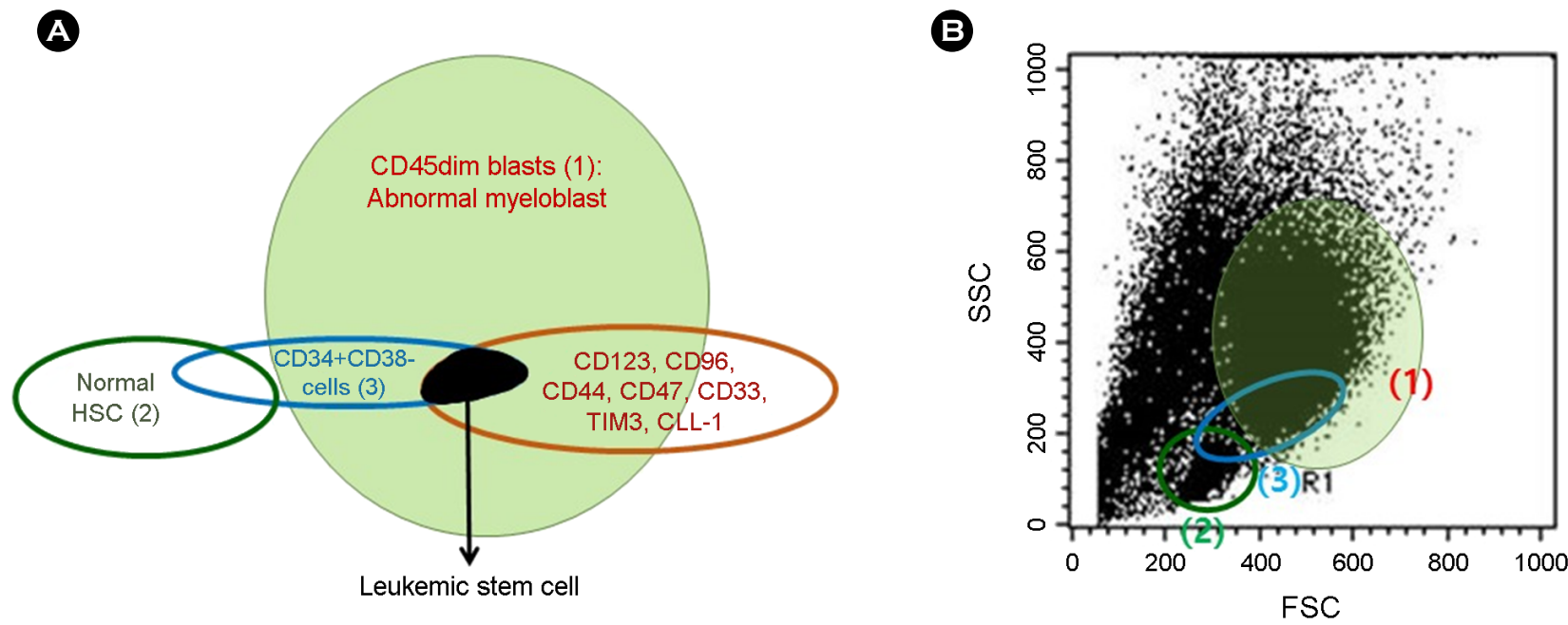

Fig. 1. (A) Schematic diagram showed LSCs in CD45 dim population (1) and normal HSCs (2). Typical marker for LSCs and HSCs, CD34+CD38- cells (3) is depicted by blue circle. Emerging markers should be highly expressed on CD34+CD38- cells. (B) Forward vs. scatter plot of whole cells in AML clearly divided into mononuclear cells (2) from abnormal myeloid blasts (1).

condensed clump $(<0.4 \mathrm{~mm})$ (Lee et al., 2016; Matsushita et al., 2008) unlike in HSCs. Prospective isolation of LSCs via surface markers is possible in mononuclear cells and immature myeloblast in AML and it reveals whether isolated positive cells can function as LSCs or not in vitro. To achieve complete remission and to develop diagnosis and therapy, one of the strategies is to identify cell surface markers that can distinct LSCs from HSCs. So far, confirmation for several marker proteins is addressed by using specific antagonists and monoclonal antibodies in both in vitro and in vivo experiments. By using of specific markers, isolation of pure LSCs could provide basic mechanism and therapeutic clues by targeting LSCs. However, because highly enriched populations of LSCs have still displayed heterogeneous properties, combinational treatment with conventional anti-cancer drugs should be recommended under continuous surveillance with specific inhibition.

\section{Phenotypes of LSCs in AML II - differential expression between LSC and HSC}

A phenotypic studies have shown that LSCs are typically: CD34+, CD38-, CD90-, CD117-, CD123+ (IL3Ralpha), CD96+, CD44+, CD47+, CD33+, TIM-3+ (CD366), C-type lectin like molecule-1 (CLL-1) (Blair et al., 1997; Blair et al., 2000; Jin et al., 2009; Jin et al., 2006; Majeti et al., 2009; Walter et al., 2012; Kikushige et al., 2010; van Rhenen et al., 2007). These marker proteins are mainly distributed in LSCs, compared to that of HSCs, showing induction of leukemia. Based on these, many studies have presented rapid advance in phenotypic characterization against ambiguity of LSCs. Features of the LSC marker protein were as follows: First, LSCs with marker proteins revealed a frequent expression in $\mathrm{CD} 34+\mathrm{CD} 38$ - primitive leukemic cells with rare or no expression of HSCs and lineage markers. Second, isolated positive cells have cancer biologic activities in vivo and in vitro, compared to that of negative cells. Third is high ability for long-term repopulating in engrafting $\mathrm{NOD} / \mathrm{LtSz}-$ scid $\mathrm{IL}-2 \mathrm{R} \gamma^{\text {null }}$ mice regardless of low number of injected cells. Furthermore, overexpressed proteins are directly associated with shorter overall survival in AML cohorts depending on specific subtypes and are correlated to AML linked mutation genes such as FLT-3, NPM1. Collectively, it indicated that specific inhibition of markers could exactly target LSCs in terms of FAB subtype and might pave the way in treatment with specific monoclonal antibody, when patients received autologous transplantation. Approximate distribution by markers and general scattering of cells is presented by Fig. 1. More detailed LSC phenotype, which 
might coexist in $\mathrm{Lin}^{-} \mathrm{CD} 34^{+} \mathrm{CD} 38^{-} \mathrm{CD} 90^{-} \mathrm{CD} 45 \mathrm{RA}^{+}$and

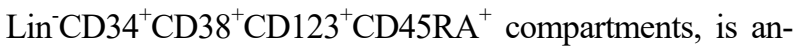
nounced after discovery of CD34+CD38- cells. In common, these cell populations are mostly similar to normal granulocyte-macrophage progenitor (GMP) and lymphoidprimed multipotent progenitor (LMPP) (Goardon et al., 2011). Indeed, because not all AML-LSCs restricted in CD34+ CD38- phenotype, we cannot exclude phenotypic diversity with molecular complication of AML-LSCs. If dynamic status of LSCs including cytogenetic mutation, AML subtype, therapeutic status, response of chemo-resistance, and gene mutations is simultaneously and scrupulously considered, it may be helpful to target LSCs effectively.

\section{Potential drugs, monoclonal antibodies that correspond to each target}

Despite of heterogeneity of LSCs, target molecules and drugs have been continuously developed and are undergoing clinical trials. Perpetual challenge for developing drugs could ultimately provide LSC elimination to be completed. Among these, monoclonal antibodies were well positioned and their therapeutic potentials owing to their target antigen specificity and minimal toxicity were highlighted. In recent years, a number of surface antigens have been identified as mentioned above. Representative monoclonal antibodies applying clinical trials are CD44, CD47, CD33, CLL-1 and CD123. And these marker proteins have strongly demonstrated antitumoral effects in NOD/LtSz-scid IL-2R $\gamma^{\text {null }}$ mice and their application in clinic phase is in progress. CD123 is known as interleukin-3 receptor alpha and is expressed on normal HSC as well as LSCs (Testa et al., 2002; Taussig et al., 2005). CD123 is over-expressed in AML patients, who have fmslike tyrosine kinase 3- internal tandem duplication (FLT3ITD) and nucleophosmin 1 (NPM1) gene mutation with over 72\% (Rollins-Raval et al., 2013). FLT3-ITD expressed patient have been regarded as high risk group with recurrence and Rollins showed that CD123 expression in CD34+CD38compartment may predict relapse in FLT3-ITD groups, implicating specificity of monoclonal antibody depending on patient's status. CD123 targeting monoclonal antibody can suppress LSC activity with effective inhibition, which is achieved by Fc dependent mechanism, resulting in blocking homing and engraftment of LSCs (Jin et al., 2009). When Fc receptor, but not Fab region was blocked either by immunoglobulin or immunosuppressive antibodies, AMLLSC repopulating activity was remarkably decreased in the CD34+CD123+ cells. It suggested the importance of receptor phosphorylation via Fc receptor. High enriched CD123 cells in CD34+CD38- compartment is attested as a LSCs. CD44 is a family of transmembrane glycoprotein, mainly linked to hyaluronan acid, and promotes homing of LSCs and HSCs into endosteal niche (Lapidot et al., 2005). It is known that LSC homing is also dramatically suppressed by inhibition of CD44, leading to BM niche control (Jin et al., 2006). Monoclonal antibody for CD44 already entered into preclinical phase 1 in solid tumor, but not AML yet (Vugts et al., 2014; Willemien et al., 2016). In case of CD47, it is widely expressed in the human tissues and blood lineage

Table 1. Monoclonal antibodies in AML. - Clinicaltrials.gov

\begin{tabular}{lllll}
\hline \hline Target marker & \multicolumn{1}{c}{ Active and recruiting trials } & \multicolumn{1}{c}{ Status } & Expression on HSCs & Expression on LSCs \\
\hline CD123 & NCT00397579 & Active, not recruting & Positive & Strongly positive \\
& NCT01632852 & Completed & Strongly positive \\
CD44 & $\begin{array}{l}\text { Clinical phase I in solid } \\
\text { tumor, but not AML }\end{array}$ & Active, recruting & Positive & Strongly positive \\
CD47 & NCT02641002 & Recruting & Positive & Strongly positive \\
CD96 & Preclinical phase & N/A & Positive & Positive \\
CLL-1 & NCT03038230 & Currently recruting & Negative & Strongly positive \\
CD33 & NCT02326584 & Active, not recruting & Strongly positive & \\
\hline
\end{tabular}


cells including myeloid cells and is over-expressed in myelodysplastic syndromes as well as severe AML. In xenografting, blocking of CD47 via monoclonal antibody or neutralization induces active status of macrophages and leads to anti-leukemic effect by activation of immune cell including macrophage (Majeti et al., 2009; Theocharides et al., 2012). CD96 is a type I membrane protein and immunoglobulin family, which is very similar to CD226. CD96 is overall enriched in $90 \%$ of LSCs, very low coexistence of HSCs is known with 5\% (Hosen et al., 2007). Interestingly, CD96 is preferentially expressed on CD34+CD38-CD123+ cell population and can be explored diagnosis indicator for poor outcome (Chávez-González et al., 2014). Regardless of the ambiguous mechanism of CD33, it is considered as a key marker protein in AML due to strong expression on LSCs with CD34+CD38- fractions. CD33 is expressed both in LSCs and HSCs. but, CD33 is discriminated by CD34+CD38-CD123+ cells in AML-LSCs, but not HSCs.
Based on previous results, Clinical phase III for CD33 is completed in AML patients (Petersdorf et al., 2013). Based on above data, $\mathrm{CD} 123+$ phenotype is strongly highlighted in CD34+CD38- cells and showed results of the most upgraded clinic application with monoclonal antibody. In clinic, therapeutic targeted monoclonal antibodies were provided by Table 1. Ultimately, finding of decent marker for LSCs will need to investigate biology of LSCs and to advance clinic application.

\section{CONCLUSION}

I simply summarized a surface markers of LSCs and targeting monoclonal antibodies in clinical trials (Fig. 2). Monoclonal antibodies in clinical trials are undergoing to investigate their anti-leukemic effects in AML. Specific inhibition of LSCs by monoclonal antibody will present a novel leukemic therapeutic avenue, in spite of individual

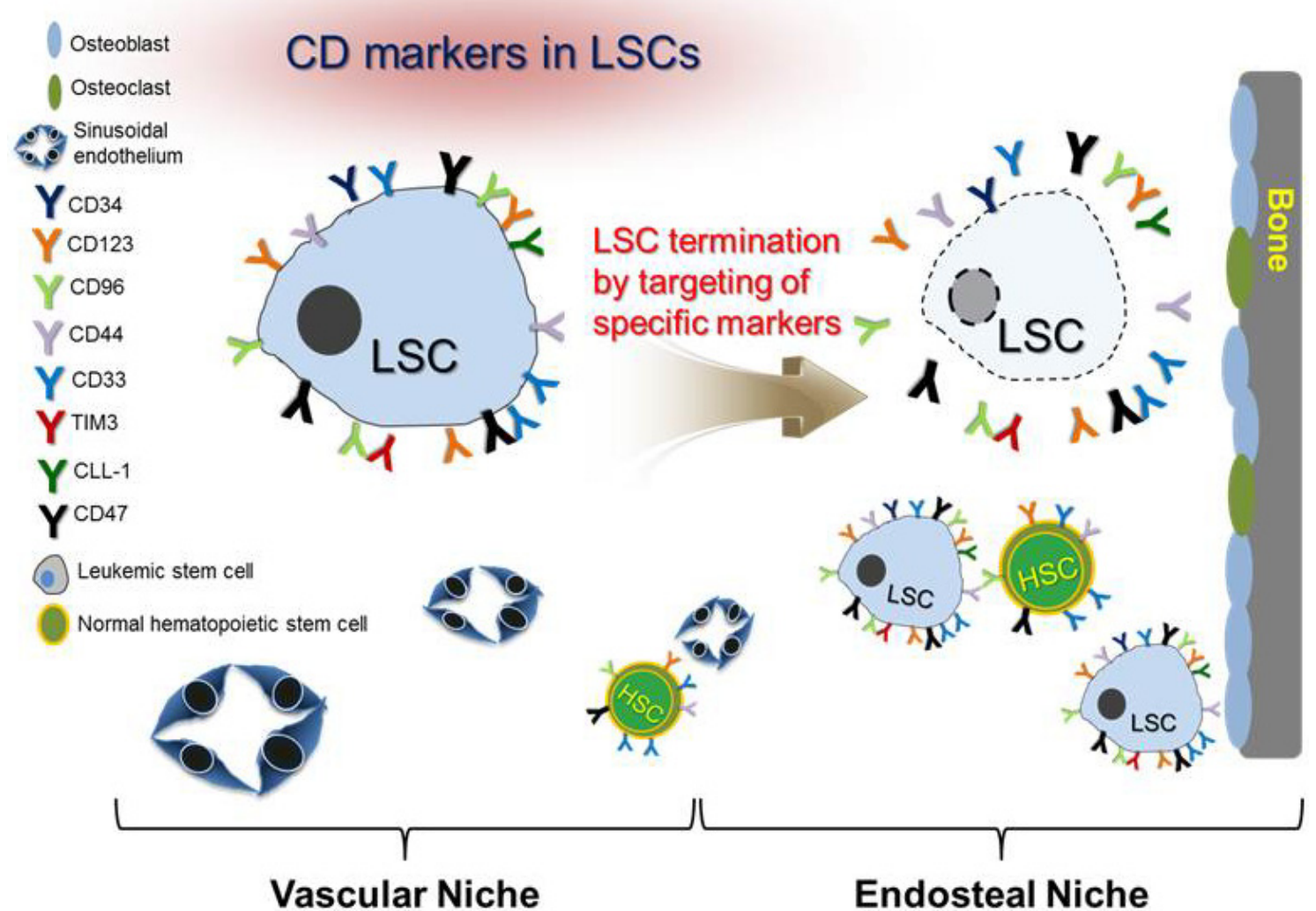

Fig. 2. Schematic diagram of markers for LSCs and HSCs in bone marrow. 
variation of AML. Since LSCs are regarded as being resistant to chemotherapeutic agents, marker study in LSCs is crucial for clinical application. To completely eradicate AML, which is recurred by LSCs, a better understanding of LSCs properties and mechanism should be accompanied. Expected outcomes in clinic phase will be yielded by targeting LSCs using bona fide marker in the next strategies.

\section{Conflict of interest}

The author declares that I have no conflict of interests.

\section{REFERENCES}

Ailles LE, Gerhard B, Hogge DE. Detection and characterization of primitive malignant and normal progenitors in patients with acute myelogenous leukemia using long-term coculture with supportive feeder layers and cytokines. Blood. 1997. 90: 2555-2564.

Bhatia M, Wang JC, Kapp U, Bonnet D, Dick JE. Purification of primitive human hematopoietic cells capable of repopulating immune-deficient mice. Proceedings of the National Academy of Sciences of the United States of America. 1997. 94: 5320 -5325 .

Blair A, Hogge DE, Ailles LE, Lansdorp PM, Sutherland HJ. Lack of expression of thy-1 (CD90) on acute myeloid leukemia cells with long-term proliferative ability in vitro and in vivo. Blood. 1997. 89: 3104-3112.

Blair A, Sutherland HJ. Primitive acute myeloid leukemia cells with long-term proliferative ability in vitro and in vivo lack surface expression of c-kit (CD117). Experimental Hematology. 2000. 28: 660-671.

Bonnet D, Dick JE. Human acute myeloid leukemia is organized as a hierarchy that originates from a primitive hematopoietic cell. Nature Medicine. 1997. 3: 730-737.

Bruedigam C, Bagger FO, Heidel FH, Paine Kuhn C, Guignes S, Song A, Austin R, Vu T, Lee E, Riyat S, Moore AS, Lock RB, Bullinger L, Hill GR, Armstrong SA, Williams DA, Lane SW. Telomerase inhibition effectively targets mouse and human AML stem cells and delays relapse following chemotherapy. Cell Stem Cell. 2014. 15: 775-790.

Chávez-González A, Dorantes-Acosta E, Moreno-Lorenzana D, Alvarado-Moreno A, Arriaga-Pizano L, Mayani H. Expression of CD90, CD96, CD117, and CD123 on different hematopoietic cell populations from pediatric patients with acute myeloid leukemia. Archives of Medical Research. 2014. 5: 343-350.

Dieter SM, Ball CR, Hoffmann CM, Nowrouzi A, Herbst F, Zavidij O, Abel U, Arens A, Weichert W, Brand K, Koch M, Weitz J, Schmidt M, von Kalle C, Glimm H. Distinct types of tumorinitiating cells form human colon cancer tumors and metastases. Cell Stem Cell. 2011. 9: 357-365.

Eppert K, Takenaka K, Lechman ER, Waldron L, Nilsson B, van Galen P, Metzeler KH, Poeppl A, Ling V, Beyene J, Canty AJ, Danska JS, Bohlander SK, Buske C, Minden MD, Golub TR, Jurisica I, Ebert BL, Dick JE. Stem cell gene expression programs influence clinical outcome in human leukemia. Nature Medicine. 2011. 17: 1086-1093.

Feller N, van der Pol MA, van Stijn A, Weijers GW, Westra AH, Evertse BW, Ossenkoppele GJ, Schuurhuis GJ. MRD parameters using immunophenotypic detection methods are highly reliable in predicting survival in acute myeloid leukaemia Leukemia. 2004. 18: 1380-1390.

Ferrara F, Schiffer CA. Acute myeloid leukaemia in adults. Lancet. 2013. 381: 484-495.

Goardon N, Marchi E, Atzberger A, Quek L, Schuh A, Soneji S, Woll P, Mead A, Alford KA, Rout R, Chaudhury S, Gilkes A, Knapper S, Beldjord K, Begum S, Rose S, Geddes N, Griffiths M, Standen G, Sternberg A, Cavenagh J, Hunter H, Bowen D, Killick S, Robinson L, Price A, Macintyre E, Virgo P, Burnett A, Craddock C, Enver T, Jacobsen SE, Porcher C, Vyas P. Coexistence of LMPP-like and GMP-like leukemia stem cells in acute myeloid leukemia. Cancer Cell. 2011. 19: 138-152.

Hamburger AW, Salmon SE. Primary bioassay of human tumor stem cells. Science. 1977. 197: 461-463.

Hosen N, Park CY, Tatsumi N, Oji Y, Sugiyama H, Gramatzki M, Krensky AM, Weissman IL. CD96 is a leukemic stem cellspecific marker in human acute myeloid leukemia. Proceedings of the National Academy of Sciences of the United States of America. 2007. 104: 11008-11013.

Hope KJ, Jin L, Dick JE. Acute myeloid leukemia originates from a hierarchy of leukemic stem cell classes that differ in selfrenewal capacity. Nature Immunology. 2004. 5: 738-743.

Ishikawa F, Yoshida S, Saito Y, Hijikata A, Kitamura H, Tanaka S, Nakamura R, Tanaka T, Tomiyama H, Saito N, Fukata M, Miyamoto T, Lyons B, Ohshima K, Uchida N, Taniguchi S, Ohara O, Akashi K, Harada M, Shultz LD. Chemotherapyresistant human AML stem cells home to and engraft within the bone-marrow endosteal region. Nature Biotechnology. 2007. 25: 1315-1321. 
Jin L, Hope KJ, Zhai Q, Smadja-Joffe F, Dick JE. Targeting of CD44 eradicates human acute myeloid leukemic stem cells. Nature Medicine. 2006. 12: 1167-1174.

Jin L, Lee EM, Ramshaw HS, Busfield SJ, Peoppl AG, Wilkinson L, Guthridge MA, Thomas D, Barry EF, Boyd A, Gearing DP, Vairo G, Lopez AF, Dick JE, Lock RB. Monoclonal antibodymediated targeting of CD123, IL-3 receptor alpha chain, eliminates human acute myeloid leukemic stem cells. Cell Stem Cell. 2009. 5: 31-42.

Jordan CT, Guzman ML, Noble M. Cancer stem cells. The New England Journal of Medicine. 2006. 355: 1253-1261.

Kikushige Y, Shima T, Takayanagi S, Urata S, Miyamoto T, Iwasaki H, Takenaka K, Teshima T, Tanaka T, Inagaki Y, Akashi K. TIM-3 is a promising target to selectively kill acute myeloid leukemia stem cells. Cell Stem Cell. 2010. 7: 708-717.

Lacombe F, Durrieu F, Briais A, Dumain P, Belloc F, Bascans E, Reiffers J, Boisseau MR, Bernard P. Flow cytometry CD45 gating for immunophenotyping of acute myeloid leukemia. Leukemia. 1997. 11: 1878-1886.

Lapidot T, Dar A, Kollet O. How do stem cells find their way home? Blood. 2005. 106: 1901-1910.

Lapidot T, Sirard C, Vormoor J, Murdoch B, Hoang T, CaceresCortes J, Minden M, Paterson B, Caligiuri MA, Dick JE. A cell initiating human acute myeloid leukaemia after transplantation into scid mice. Nature. 1994. 367: 645-648.

Lee JY, Han AR, Lee SE, Min WS, Kim HJ. Co-culture with podoplanin+ cells protects Leukemic blast cells with leukemiaassociated antigens in the tumor microenvironment. Molecular Medicine Reports. 2016. 13: 3849-3857.

Majeti R, Chao MP, Alizadeh AA, Pang WW, Jaiswal S, Gibbs $\mathrm{KD}$, Jr., van Rooijen N, Weissman IL. CD47 is an adverse prognostic factor and therapeutic antibody target on human acute myeloid leukemia stem cells. Cell. 2009. 138: 286-299.

Matsushita H, Nakajima H, Nakamura Y, Tsukamoto H, Tanaka Y, Jin G, Yabe M, Asai S, Ono R, Nosaka T, Sugita K, Morimoto A, Hayashi Y, Hotta T, Ando K, Miyachi H. C/EBPalpha and $\mathrm{C} / \mathrm{EBP}$ varepsilon induce the monocytic differentiation of myelomonocytic cells with the MLL-chimeric fusion gene. Oncogene. 2008. 27: 6749-6760.

Menke-van der Houven van Oordt CW, Gomez-Roca C, van Herpen C, Coveler AL, Mahalingam D, Verheul HM, van der Graaf WT, Christen R, Ruttinger D, Weigand S, Cannarile MA, Heil F, Brewster M, Walz AC, Nayak TK, Guarin E, Meresse V, Le Tourneau C. First-in-human phase i clinical trial of RG7356, an anti-CD44 humanized antibody, in patients with advanced, cd44-expressing solid tumors. Oncotarget. 2016 7: 80046-80058.

Petersdorf SH, Kopecky KJ, Slovak M, Willman C, Nevill T, Brandwein J, Larson RA, Erba HP, Stiff PJ, Stuart RK, Walter RB, Tallman MS, Stenke L, Appelbaum FR. A phase 3 study of gemtuzumab ozogamicin during induction and postconsolidation therapy in younger patients with acute myeloid leukemia. Blood. 2013. 121: 4854-4860.

Rollins-Raval M, Pillai R, Warita K, Mitsuhashi-Warita T, Mehta R, Boyiadzis M, Djokic M, Kant JA, Roth CG. CD123 immunohistochemical expression in acute myeloid leukemia is associated with underlying FLT3-ITD and NPM1 mutations. Applied Immunohistochemistry \& Molecular Morphology. 2013. 21: 212-217.

Taussig DC, Pearce DJ, Simpson C, Rohatiner AZ, Lister TA, Kelly G, Luongo JL, Danet-Desnoyers GA, Bonnet D. Hematopoietic stem cells express multiple myeloid markers: Implications for the origin and targeted therapy of acute myeloid leukemia. Blood. 2005. 106: 4086-4092.

Testa U, Riccioni R, Militi S, Coccia E, Stellacci E, Samoggia P, Latagliata R, Mariani G, Rossini A, Battistini A, Lo-Coco F, Peschle C. Elevated expression of IL-3Ralpha in acute myelogenous leukemia is associated with enhanced blast proliferation, increased cellularity, and poor prognosis. Blood. 2002. 100: 2980-2988

Theocharides AP, Jin L, Cheng PY, Prasolava TK, Malko AV, Ho JM, Poeppl AG, van Rooijen N, Minden MD, Danska JS, Dick JE, Wang JC. Disruption of sirpalpha signaling in macrophages eliminates human acute myeloid leukemia stem cells in xenografts. Journal of Experimental Medicine. 2012. 209: 1883-1899.

van Rhenen A, van Dongen GA, Kelder A, Rombouts EJ, Feller N, Moshaver B, Stigter-van Walsum M, Zweegman S, Ossenkoppele GJ, Jan Schuurhuis G. The novel aml stem cell associated antigen CLL-1 aids in discrimination between normal and leukemic stem cells. Blood. 2007. 110: 2659-2666.

Vugts DJ, Heuveling DA, Stigter-van Walsum M, Weigand S, Bergstrom M, van Dongen GA, Nayak TK. Preclinical evaluation of 89zr-labeled anti-CD44 monoclonal antibody RG7356 in mice and cynomolgus monkeys: Prelude to phase 1 clinical studies. MAbs. 2014. 6: 567-575.

Walter RB, Appelbaum FR, Estey EH, Bernstein ID. Acute myeloid leukemia stem cells and CD33-targeted immunotherapy. Blood. 2012. 119: 6198-6208. 